\title{
Spectrophotometric determination of pefloxacin mesylate in pharmaceuticals
}

\author{
KANAKAPURA BASAVAIAH* \\ HULLIKAL CHANDRASHEKAR PRAMEELA \\ BANKAVADI CHIKKASWAMY SOMASHEKAR \\ Department of Chemistry \\ University of Mysore \\ Manasagangotri \\ Mysore-570 006, India
}

Accepted January 11, 2007

\begin{abstract}
A spectrophotometric method is described for assay of pefloxacin mesylate (PFM) in bulk drug and in tablets. The method is based on back extraction of the bromophenol blue dye at pH 5.2 from the dye-drug ion pair followed by measurement of the dye absorbance at 590 $\mathrm{nm}$. The working conditions of the method were investigated and optimized. Beer's law plot showed a good correlation in the concentration range of $0.15-1.25 \mu \mathrm{g} \mathrm{mL}^{-1}$. Sensitivity indices such as molar absorptivity, limits of detection and quantification are reported. Intra-day and inter-day precision, and accuracy of the methods were established according to the ICH guidelines, and the $e_{\mathrm{r}}$ values were in the range of -1.7 to $1.8 \%$ with RSD values ranging from 1.0 to $1.1 \%$. The method was successfully applied to the assay of PFM in tablet preparations with recoveries varying from 97.5 to $101.9 \%$, with standard deviation in the range of 0.6 to 1.9 . The results were statistically compared with those of the reference method by applying Student's $t$-test and $F$-test. Accuracy evaluated by means of the spike recovery method, range from 97.0 to $106.0 \%$, with precision better than $3 \%$.
\end{abstract}

Keywords: pefloxacin mesylate, assay, spectrophotometry, bromophenol blue, pharmaceuticals

Pefloxacin mesylate dihydrate (PFM) is a fluorinated quinolone structurally related to nalidixic acid. Chemically, PFM, is 1-ethyl-6-fluoro-1,4-dihydro-7-(4-methyl-1-peperazinyl)-4-oxo-3-quinolinecarboxylic acid, methane sulfonate dihydrate (Fig. 1). It is an antibacterial drug, which is highly effective against both Gram-negative and Gram-positive pathogens that are resistant to other antibacterials (1). The therapeutic importance of PFM has necessitated the development of analytical methods for its determination in dosage forms in compliance with good manufacturing standards. The drug is official in British and European Pharmacopoeias which describe a potentiometric non-aqueous titration procedure for its assay $(2,3)$. The drug has been determined in pharmaceutical formulations by a variety of analytical techniques such as UV-spectrophotometry $(4,5)$,

* Correspondence, e-mail: basavaiahk@yahoo.co.in 


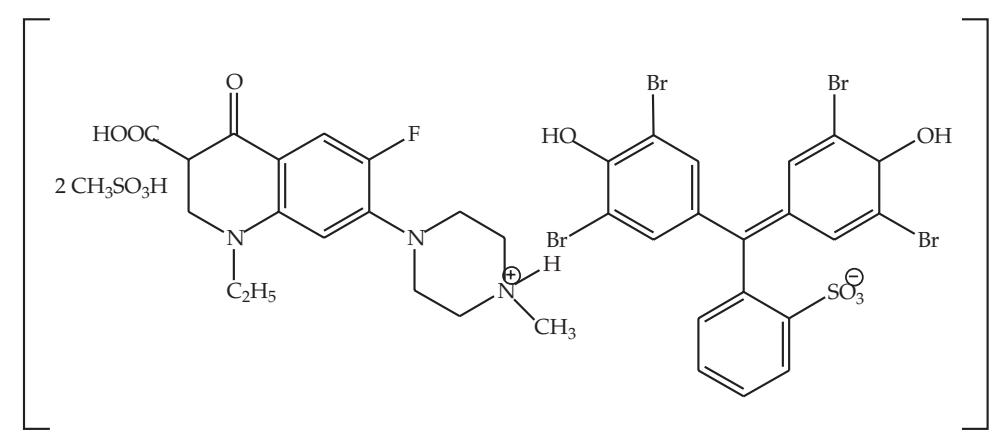

PFM-BPB complex (pH 3.0)<smiles>CCCCN1CC(C(=O)O)C(=O)c2cc(F)c(N3CCN(C)CC3)cc21</smiles>

Fig. 1. Tentative reaction scheme.

spectrofluorimetry $(6,7)$, capillary electrophoresis (8), polarography (9) and high performance liquid chromatography (10-14). A few visible spectrophotometric methods based on acid-base (15), redox (7, 16-18), oxidative coupling (19), complex formation (20-24) reactions have been earlier reported for the determination of PFM in dosage forms. The reported methods have their respective advantages and disadvantages as indicated in Table 1. Therefore, it was considered desirable to develop an additional assay method suitable for rapid and reliable quality control of PFM formulations. In this study, the visible spectrophotometric approach was followed to develop a sensitive and selective procedure for the determination of PFM in commercial dosage forms.

\section{EXPERIMENTAL}

\section{Apparatus}

A Systronics model 106 digital spectrophotometer (Systronics India Ltd., India) with 1 -cm matched quartz cells was used for all absorbance measurements. 
Table I. Comparision of performance characteristics of the proposed method with the reported methods

\begin{tabular}{|c|c|c|c|c|c|}
\hline Reagent & $\begin{array}{l}\lambda_{\max } \\
(\mathrm{nm})\end{array}$ & $\begin{array}{l}\text { Beer's law } \\
\text { range } \\
\left(\mu \mathrm{g} \mathrm{mL}^{-1}\right)\end{array}$ & $\begin{array}{c}\varepsilon \\
\left(\mathrm{L} \mathrm{mol}^{-1} \mathrm{~cm}^{-1}\right)\end{array}$ & Remarks & Ref. \\
\hline Vanadium(V) & 766 & $10-40$ & & $\begin{array}{l}\text { Heating, } 30 \mathrm{~min} \text {, narrow } \\
\text { linear range, less sensitive }\end{array}$ & 7 \\
\hline $\mathrm{NaOH}$-phenol red & 560 & $5-40$ & $5.91 \times 10^{3}$ & $\begin{array}{l}\text { Critical dependence on } \\
\mathrm{NaOH} \text { concentration }\end{array}$ & 15 \\
\hline Folin-Ciocalteau reagent & 670 & $10-45$ & $2.8 \times 10^{3}$ & $\begin{array}{l}\text { Less selective, less sensitive } \\
\text { and narrow linear and } \\
\text { dynamic range }\end{array}$ & 16 \\
\hline Iron(III) chloride & 440 & $10-100$ & & $\begin{array}{l}\text { Less sensitive, shorter } \\
\text { wavelength }\end{array}$ & 17 \\
\hline Iron(III) chloride & 440 & $8-14$ & & $\begin{array}{l}\text { Narrow linear range, } \\
\text { shorter wavelength }\end{array}$ & 18 \\
\hline a) Cerium(IV)-MBTH & 640 & $4-14$ & $1.33 \times 10^{4}$ & $\begin{array}{l}\text { Critical acid concentration, } \\
\text { narrow linear range }\end{array}$ & $\begin{array}{l}19 \\
19\end{array}$ \\
\hline b) Ammonium molybdate & 365 & $10-60$ & $3.00 \times 10^{4}$ & $\begin{array}{l}\text { Critical acid concentration, } \\
\text { shorter wavelength }\end{array}$ & \\
\hline Iron(III) nitrate $/ \mathrm{NaNO}_{3}$ & 404 & $4.7-13.7$ & $4.8 \times 10^{3}$ & $\begin{array}{l}\text { Shorter wavelength, narrow } \\
\text { linear range, less sensitive }\end{array}$ & 20 \\
\hline $\begin{array}{l}\text { a) Chloranilic acid } \\
\text { b) Tetracyanoethylene } \\
\text { c) DDQ }\end{array}$ & $\begin{array}{l}520 \\
290 \\
460\end{array}$ & & & $\begin{array}{l}\text { Non-aqueous medium, } \\
\text { usually less sensitive }\end{array}$ & 21 \\
\hline Ammonium reineckate & 527 & $2-36$ & & $\begin{array}{l}\text { Cumbersome procedure - } \\
\text { precipitation, filtration, } \\
\text { dissolution in acetone }\end{array}$ & 22 \\
\hline Methyl orange & 424 & $4-40$ & & & 23 \\
\hline Bromocresol green & 420 & $2-16$ & & & 24 \\
\hline Bromophenol blue & 590 & $0.15-1.25$ & $2.40 \times 10^{5}$ & Highly sensitive & $\begin{array}{c}\text { this } \\
\text { paper }\end{array}$ \\
\hline
\end{tabular}

MBTH - 3-methylbenzothiazoline-2-one hydrazone DDQ - 2,3-dichloro-5,6-dicyano- $p$-benzoquinone

\section{Reagents and materials}

All chemicals used were of analytical reagent grade and all solutions were freshly prepared in doubly distilled water. Spectrophotometric grade chloroform (Ranbaxy Fine Chem, Ltd., India) was used for extraction.

Phthalate buffers ( $\mathrm{pH} 3.0$ and 5.2) were prepared by adjusting the $\mathrm{pH}$ of $0.1 \mathrm{~mol} \mathrm{~L}^{-1}$ potassium hydrogen phthalate (S. d. Fine Chem., India) with $0.1 \mathrm{~mol} \mathrm{~L}^{-1}$ hydrochloric acid and $0.1 \mathrm{~mol} \mathrm{~L}^{-1}$ sodium hydroxide, respectively. A $0.1 \%$ solution of Bromophenol blue (BPB) was prepared by dissolving the dye (Rankem, India, 95\% dye content) in water and filtering it to remove the insoluble residue. 
Pharmaceutical grade PFM was kindly gifted by Cipla India Ltd. (India). A stock standard solution containing $1 \mathrm{mg} \mathrm{mL}^{-1}$ of PFM was prepared in water. Working standard solution equivalent to $5 \mu \mathrm{g} \mathrm{mL} \mathrm{m}^{-1}$ PFM was obtained by appropriate dilution of stock solution.

The following dosage forms containing PFM were purchased from local commercial sources: A - Peflex tablets (Wockhardt, India), 200 and $400 \mathrm{mg}$ of PFM, B - Pefbid tablets (Megacarem, India), $400 \mathrm{mg}$ of PFM, C - Qucin tablets (Aristo Pharma Pvt. Ltd. India), $400 \mathrm{mg}$ of PFM, and D - Peflobid injections equivalent to $2 \mathrm{mg} \mathrm{mL}^{-1}$ PFM (Cadila, India).

\section{Analytical procedures}

Calibration graph. - Twenty $\mathrm{mL}$ of PFM solution $(5 \mu \mathrm{g} \mathrm{mL}-1)$ was pipetted into a $125-\mathrm{mL}$ separating funnel, $4 \mathrm{~mL}$ of $\mathrm{BPB}(0.1 \%)$ and $20 \mathrm{~mL}$ phthalate buffer ( $\mathrm{pH} 3.0)$ were added and the total volume of aqueous phase was made up to $60 \mathrm{~mL}$ with water. Chloroform $(20 \mathrm{~mL})$ was added and the contents were shaken for $1 \mathrm{~min}$; the separated chloroform layer was dried over anhydrous sodium sulphate and collected in a 25-mL calibrated flask. Different aliquots of the chloroform extract (drug-dye ion-pair equivalent to $5 \mu \mathrm{g} \mathrm{mL}{ }^{-1}$ PFM) were accurately measured and transferred into a series of $125-\mathrm{mL}$ separating funnels and then, $5 \mathrm{~mL}$ of phthalate buffer ( $\mathrm{pH}$ 5.2) added to each separating funnel. The contents were shaken for $1 \mathrm{~min}$ and the absorbance of the separated aqueous layer was measured at $590 \mathrm{~nm}$ against a reagent blank.

Detection and quantification limits. - The limit of detection $(L O D)$ and limit of quantification $(L O Q)$ were calculated according to the current $\mathrm{ICH}$ guidelines as the ratio of 3.3 and 10 standard deviations of the blank $(n=7)$, respectively, and the slope of the calibration line (25).

Procedure for dosage forms. - Twenty PFM tablets were chosen randomly from a total number of 50. They were weighed accurately and ground into a fine powder. An amount of powder equivalent to approximately $20 \mathrm{mg}$ of PFM was accurately weighed into a 100-mL calibrated flask, $50 \mathrm{~mL}$ of water was added and the content was shaken for 15-20 min. Then, the volume was finally diluted to the mark with water, mixed well and filtered using a Whatman No. 42 filter paper. The first 10-mL portion of the filtrate was discarded, and the tablet extract $(200 \mu \mathrm{g} \mathrm{mL}-1$ in PFM) was diluted with water to get $5 \mu \mathrm{g} \mathrm{mL}-1$ PFM solution for assay. The contents of 20 ampoules containing injectables were pooled and an aliquot equivalent to $20 \mathrm{mg}$ of PFM was accurately measured and diluted to $100 \mathrm{~mL}$ in a calibrated flask and mixed. After necessary dilution, the solution was assayed as stated before.

Selectivity studies. - As synthetic mixture consisting of PFM, talc, starch, lactose, gum acacia, sodium alginate, magnesium stearate, calcium gluconate, and calcium dihydrogenorthophosphate in the ratio 1:1.5:2:1.5:0.5:2.5:3.0:1:0.5 was prepared by thorough mixing of the constituents. An amount of the mixture equivalent to $20 \mathrm{mg}$ of PFM was accurately weighed into a $100-\mathrm{mL}$ calibrated flask and the drug was extracted with water and the steps described under the assay of dosage forms were followed to determine the percent recovery of PFM. The results are presented in Table V. 


\section{RESULTS AND DISCUSSION}

The described method is based on the formation of a chloroform soluble ion-pair between PFM and BPB followed by measurement of the back-extracted dye.

\section{Optimization of experimental conditions}

While studying the effect of $\mathrm{pH}$, the drug-dye ion-pair formation was found to be critically dependent on the $\mathrm{pH}$ of the aqueous phase and at $\mathrm{pH}$ values higher than 4.8 no ion-pair was formed, i.e., the ion-pair was found to break into its constituent ions. This observation was exploited to develop a highly sensitive method for PFM. In this method, the ion-pair formed at $\mathrm{pH} 3.0$ and extracted into chloroform was back-extracted with a buffer of $\mathrm{pH} 5.2$ and the absorbance of the aqueous buffer phase was measured at 590 nm (Fig. 2).

Several organic solvents such as benzene, toluene, cyclohexane, carbon tetrachloride, methylene chloride and $i$-amylalcohol in addition to chloroform were examined for their ability to extract the drug-dye ion-pair. The latter was found to be the most suitable solvent in terms of extraction efficiency.

Optimum conditions for quantitative extraction of the dye from the drug-dye ion-pair were also investigated. The absorbance was maximal and constant over the $\mathrm{pH}$ range 4.8-5.6; hence, $\mathrm{pH} 5.2$ was selected. The extraction was also affected by the nature of the buffer employed. Of the several ( $\mathrm{pH}$ 5.2) buffers tested, such as phthalate- $\mathrm{NaOH}$,

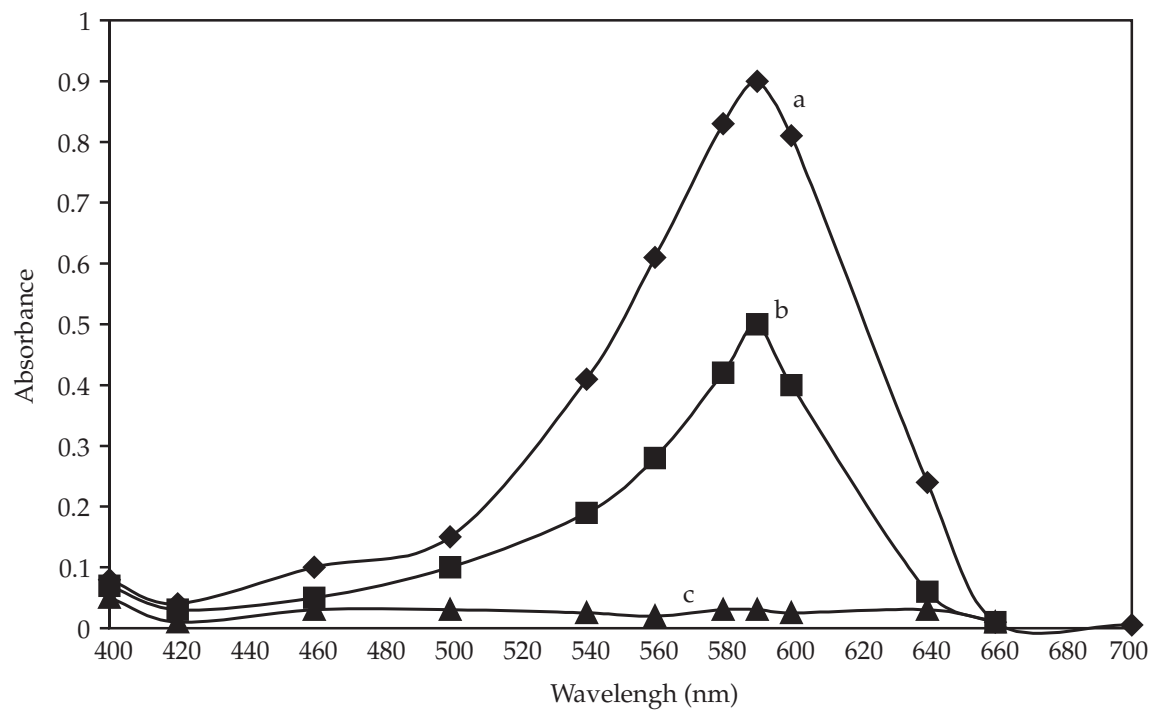

Fig. 2. Absorption spectra of back extracted dye:

a) $1.13 \mu \mathrm{g} \mathrm{mL}-1$ PFM, b) $0.63 \mu \mathrm{g} \mathrm{mL} \mathrm{m}^{-1}$ of PFM, c) blank. 
acetate-acetic acid, succinic acid-borax, the first buffer was found to provide efficient extraction. A single extraction with $5 \mathrm{~mL}$ of buffer was found to be adequate for the concentration range investigated. Shaking times ranging from 0.5 to 3 min produced no change in absorbance; so a one min shaking time was selected. The absorbance of the aqueous phase was found to be constant over several weeks.

\section{Method validation}

Under the experimental conditions described, Beer's law was obeyed over 0.15-1.25 $\mu \mathrm{g} \mathrm{mL} \mathrm{m}^{-1}$ PFM. The calculated molar absorptivity was $2.40 \times 10^{5} \mathrm{~L} \mathrm{~mol}^{-1} \mathrm{~cm}^{-1}$. The LOD and $L O Q$ values were calculated to be 0.03 and $0.10 \mu \mathrm{g} \mathrm{mL}^{-1}$, respectively. The equation relating the absorbance to concentration was:

$$
A=-0.025+0.826 \gamma(R=0.9986, n=7)
$$

where $A$ is the absorbance, $\gamma$ is concentration of PFM in $\mu \mathrm{g} \mathrm{mL}^{-1}$ and $R$ is the coefficient of correlation.

In order to determine the intra-day accuracy and precision of the methods, solutions containing three different concentrations (within the working limits) of the drug were prepared and analyzed in seven replicates. The results obtained from this investigation are summarized in Table II. The relative standard deviation $(\leq 1.1 \%)$ indicates the high intra-day precision of the methods. The accuracy defined in terms of percent deviation of the calculated concentrations $(\leq 2 \%)$ can be considered satisfactory. The inter-day precision was evaluated by performing replicate analyses on pure drug solution at three concentration levels over a period of five days by preparing all solutions afresh each day. The inter-day RSD values ranged from 1.5-3.5\%, reflecting the usefulness of the method in routine use (Table II).

Table II. Accuracy and precision of the proposed method

\begin{tabular}{ccccc}
\hline $\begin{array}{c}\text { PFM taken } \\
(\mu \mathrm{g} \mathrm{mL}-1)\end{array}$ & $\begin{array}{c}\text { PFM recoverd } \\
(\%)^{\mathrm{a}}\end{array}$ & $\begin{array}{c}\text { Intraday } \\
\text { RSD }(\%)\end{array}$ & $\begin{array}{c}\mathrm{CL} \\
\left.(\mu \mathrm{g} \mathrm{mL})^{-1}\right)\end{array}$ & $\begin{array}{c}\text { Interday precision } \\
\text { RSD }(\%)\end{array}$ \\
\hline 0.200 & 98.0 & 1.0 & $0.196 \pm 0.002$ & 1.5 \\
0.600 & 98.3 & 1.1 & $0.590 \pm 0.006$ & 2.8 \\
1.000 & 101.8 & 1.0 & $1.018 \pm 0.009$ & 3.5 \\
\hline
\end{tabular}

a Average value of seven determinations.

CL - Confidence limits at the $95 \%$ confidence level for six degrees of freedom.

The results of the selectivity studies as shown in Table V confirm that the proposed method is accurate and precise even in the presence of various excipients (recovery 97.6 $\pm 0.8 \%)$. 


\section{Application to dosage forms}

In order to demonstrate the usefulness of the proposed method, PFM was determined in authentic samples (pharmaceuticals). The results agreed with the nominal contents (recovery 97.5-101.9\%) (Table III). The results were also compared statistically by Student's $t$-test for accuracy and the variance ratio $F$-test for precision with the official potentiometric method (3) at the $95 \%$ confidence level with four degrees of freedom. The results showed that the proposed method and the official method are comparable in terms of accuracy and precision.

The reliability and accuracy of the methods were further confirmed by performing recovery studies. To a fixed and known quantity of the pre-analyzed tablet powder or injectable product, pure PFM (standard) was added at three different concentration levels, and the total was found by the proposed methods. The experiment was repeated three times at each level. The percent recoveries of the pure drug added (97.0-106.0\%), (Table IV), additionaly reveal the fair selectivity of the method.

The proposed method is simple, rapid, accurate and precise. From Table I, it is clear that the proposed spectrophotometric method is highly selective compared to most existing methods $(7,15-25)$. The most striking feature of the method is its extraordinary

Table III. Determination of pefloxacin mesylate in formulations

\begin{tabular}{|c|c|c|c|}
\hline \multirow[b]{2}{*}{ Formulation } & \multirow[b]{2}{*}{$\begin{array}{c}\text { Nominal amount } \\
(\mathrm{mg} \text { per tablet or mg per } \mathrm{mL})\end{array}$} & \multicolumn{2}{|c|}{ Recovery \pm SD, $n=5(\%)$} \\
\hline & & $\begin{array}{l}\text { Official } \\
\text { method }(3)^{\mathrm{a}}\end{array}$ & $\begin{array}{c}\text { Proposed } \\
\text { spectrophotometric } \\
\text { method }\end{array}$ \\
\hline \multirow[t]{2}{*}{ A } & 200 & $98.7 \pm 0.9$ & $\begin{array}{l}97.5 \pm 1.2 \\
t=1.78 \\
F=2.03\end{array}$ \\
\hline & 400 & $99.2 \pm 1.3$ & $\begin{array}{l}99.0 \pm 1.9 \\
t=0.21 \\
F=2.41\end{array}$ \\
\hline $\mathrm{B}$ & 400 & $98.7 \pm 0.4$ & $\begin{array}{l}99.2 \pm 0.6 \\
t=1.52 \\
F=2.12\end{array}$ \\
\hline C & 400 & $100.2 \pm 0.6$ & $\begin{array}{l}101.9 \pm 1.32 \\
t=2.77 \\
F=5.76\end{array}$ \\
\hline $\mathrm{D}$ & 2 & $98.3 \pm 0.6$ & $\begin{array}{l}99.2 \pm 1.3 \\
t=1.76 \\
F=4.75\end{array}$ \\
\hline
\end{tabular}

Tabulated $t$-value at $95 \%$ confidence level is 2.77 ; tabulated $F$-value at $95 \%$ confidence level is 6.39 .

a Non-aqueous potentiometric titration. 
Table IV. Recovery studies by the standard addition procedure

\begin{tabular}{cccc}
\hline Formulation & $\begin{array}{c}\text { PFM in formulation } \\
(\mu \mathrm{g})\end{array}$ & $\begin{array}{c}\text { PFM added } \\
(\mu \mathrm{g})\end{array}$ & $\begin{array}{c}\text { PFM recovered } \\
(\%)^{\mathrm{a}}\end{array}$ \\
\hline A (200 mg) & 0.98 & 1.0 & $103.3 \pm 1.1$ \\
& 0.98 & 2.0 & $97.0 \pm 2.1$ \\
& 0.98 & 3.0 & $103.3 \pm 1.3$ \\
A (400 mg) & 1.0 & 1.0 & $102.0 \pm 1.5$ \\
& 1.0 & 2.0 & $106.0 \pm 1.1$ \\
& 1.0 & 3.0 & $97.3 \pm 2.6$ \\
$\mathrm{D}$ & 0.99 & 1.0 & $101.0 \pm 2.7$ \\
& 0.99 & 2.0 & $97.0 \pm 3.4$ \\
& 0.99 & 3.0 & $103.3 \pm 4.1$ \\
\hline
\end{tabular}

a Mean $\pm \mathrm{SD}, n=3$.

Table V. Selectivity data

\begin{tabular}{|c|c|c|c|c|c|c|c|c|c|}
\hline \multicolumn{9}{|c|}{ Composition of synthetic mixture (mg) } & \multirow{2}{*}{$\begin{array}{c}\text { PFM } \\
\text { recovered } \\
(\%)^{\mathrm{a}}\end{array}$} \\
\hline PFM & Talc & Starch & Lactose & $\begin{array}{l}\text { Gum } \\
\text { acacia }\end{array}$ & $\begin{array}{l}\text { Sodium } \\
\text { alginate }\end{array}$ & $\begin{array}{l}\text { Magnesium } \\
\text { stearate }\end{array}$ & $\begin{array}{l}\text { Calcium } \\
\text { gluconate }\end{array}$ & $\begin{array}{l}\text { Calcium } \\
\text { DHP }\end{array}$ & \\
\hline 100 & 150 & 200 & 150 & 50 & 250 & 300 & 100 & 50 & $97.6 \pm 0.8$ \\
\hline
\end{tabular}

a Mean \pm SD, $n=5$.

sensitivity, which is comparable to that of the spectrofluorometric method. Further, owing to the high sensitivity and selectivity of the method, it might be applied for measuring PFM levels in biological fluids. Other advantages of the method include a wide linear dynamic range, unassailable stability of the colour measured (colour stable for several weeks) compared to many procedures reported earlier. This is demonstrated by the high precision of the results. Further, once the drug-dye ion-pair is prepared, further extractions seldom use chloroform, unlike reported method (25).

\section{CONCLUSIONS}

Peflaxacin mesylate has been assayed in dosage forms using visible spectrophotometry. The method can be used to monitor the content uniformity of tablets and injections, and purity of pefloxacin raw material.

Acknowledgements. - The quality control manager, Cipla India ltd., Mumbai, India is thanked for providing the pure drug as a gift. Two of the authors (HCP, BCS) thank the authorities of the University of Mysore, Mysore, for facilities. 


\section{REFERENCES}

1. K. D. Tripathi, Essentials of Medicinal Pharmacology, $3^{\text {rd }}$ ed., New Delhi 1995, p. 737.

2. British Pharmacopoeia, Her Majesty's Stationery Office, Vol. I, London 2001, pp. 1253-1254.

3. European Pharmacopoeia, $5^{\text {th }}$ ed., European Directorate for the Quality of Medicines, Council of Europe, Strasbourg 2004, p. 2194.

4. D. Mundle and S. G. Kashedikar, Spectrophotometric estimation of pefloxacin mesylate in pharmaceutical formulations, Indian Drugs 33 (1996) 407-408.

5. X. Qin, Ultra-violet spectrophotometric determination of content of pefloxacin mesylate preparations, Yaowu Fenxi Zazhi 14 (1994) 61-62; ref. Anal. Abstr. 56 (1994) 7G50.

6. A. K. S. Ahmad, M. A. Kawy and M. Nebsen, Spectrophotometric and spectrofluorimetric determination of pefloxacin, Anal. Lett. 30 (1997) 809-820.

7. H. Salem, Spectrofluorimetric, atomic absorption spectrometric and spectrophotometric determination of some fluoroquinolones, Am. J. Appl. Sci. 2 (2005) 719-729.

8. C. Fierens, S. Hillaert and W. Van den Bossche, The qualitative and quantitative determination of quinolones of first and second generation by capillary electrophoresis, J. Pharm. Biomed. Anal. 22 (2000) 763-772.

9. Y. Chen, Y. G. Li, J. G. Ge, F. M. Han and Z. B. Yuan, Polarographic study of pefloxacin mesylate and its analytical applications, Fenxi Shiyanshi 15 (1996) 76-78; ref. Anal. Abstr. 59 (1997) 2 G36.

10. N. Abanmi, I. Zaghloul, N. El-Sayed and K. I. Al-Khamis, Determination of pefloxacin and its main active metabolite in human serum by high-performance liquid chromatography, Ther. Drug Monitor. 18 (1996) 158-163.

11. G. Carlucci, G. Palumbo and P. Mazzeo, Simple and rapid analysis of pefloxacin, fenbufen and felbinac in human plasma using high performance liquid chromatography, J. Liq. Chromatogr. Relat. Technol. 19 (1996) 1107-1115.

12. S. S. Deng and R. Q. Xu, HPLC determination of pefloxacin mesylate in serum, Yaowu Fenxi Zazhi 15 (1995) 37-38; ref. Anal. Abstr. 57 (1995) 12G65.

13. A. P. Argekar, S. V. Kapadia, S. V. Raj and S. S. Kunjir, Quantitative determination of lomefloxacin, ofloxacin, pefloxacin and enrofloxacin by RP-HPLC, Indian Drugs 33 (1996) 261-266.

14. I.-P. Chen, C.-Y. Shaw and B.-L. Chang, Simultaneous determination of six quinolone antibacterial agents by HPLC, Yaowu Shipin Fenxi 4 (1996) 155-164; ref. Anal. Abstr. 59 (1997) 1 G39.

15. K. Basavaiah and H. C. Prameela, Quantitative determination of pefloxacin mesylate by residual-base neutralization method, J. Serb. Chem. Soc. 69 (2004) 403-410.

16. K. Basavaiah and H. C. Prameela, Sensitive spectrophotometric method for the determination of pefloxacin, Indian J. Chem. Technol. 9 (2002) 428-431.

17. B. S. Kuchekar and R. S. Shetty, Spectrophotometric determination of pefloxacin in dosage forms, J. Inst. Chem. (India) 65 (1993) 185.

18. A. B. Avadhanulu and A. R. R. Pantulu, Spectrophotometric determination of pefloxacin in its dosage forms, Indian Drugs 31 (1994) 258-262.

19. M. N. Reddy, M. Swapna, K. V. K. Rao and D. G. Sankar, Spectrophotometric determination of pefloxacin, Indian Drugs 35 (1998) 105-106.

20. M. Jelikic-Stankov, D. Veselinovic, D. Melesev and Z. Radovic, Spectrophotometric determination of pefloxacin in pharmaceutical preparations, J. Pharm. Biomed. Anal. 7 (1989) 1571-1577.

21. S. Mostafa, M. El-Sadek and E. A. Alla, Spectrophotometric determination of ciprofloxacin and pefloxacin through charge transfer complexation, J. Pharm. Biomed. Anal. 27 (2002) 133-142.

22. H. Salem, Colorimetric and atomic absorption spectrometric determination of some fluoroquinolone derivatives, Sci. Pharma. 72 (2004) 51-71. 
23. S. Mostafa, M. El-Sadek and E. A. Alla, Spectrophotometric determination of enrofloxacin and pefloxacin through ion-pair complex formation, J. Pharm. Biomed. Anal. 28 (2002) 173-180.

24. R. T. Sane, V. Dighe, V. V. Bapat and M. G. Gangrade, Extractive colorimetric method for the determination of pefloxacin mesylate dihydrate from pharmaceutical preparations, Indian J. Pharm. Sci. 53 (1991) 64-66.

25. ICH Harmonised Tripartite Guideline, prepared within the International Conference on the Harmonization of Technical Requirements for the Registration of Pharmaceuticals for Human Use (ICH), ICH Harmonised Tripartite Guideline, Validation of Analytical Procedures: Text and Methodology Q2 (R1), CPMP/ICH, London 1995.

\section{$S A \check{Z} E T A K$}

\section{Spektrofotometrijsko određivanje pefloksacin mesilata u ljekovitim oblicima}

KANAKAPURA BASAVAIAH, HULLIKAL CHANDRASHEKAR PRAMEELA

i BANKAVADI CHIKKASWAMY SOMASHEKAR

Opisana je spektrofotometrijska metoda za određivanje pefloksacin mesilata (PFM) kao čiste supstancije i u tabletama. Metoda se temelji na povratnoj ekstrakciji bromfenol modrila pri pH 5,2 iz ionskog para boja-ljekovita tvar te mjerenju apsorbancije boje na $590 \mathrm{~nm}$. Ispitivani su i optimirani reakcijski uvjeti. Sustav slijedi Beerov zakon u koncentracijskom rasponu $0,15-1,25 \mathrm{Mg} \mathrm{mL}^{-1}(R=0,9986)$. Prema važećim ICH uputama procijenjeni su indeksi osjetljivosti kao što su molarni apsorpcijski koeficijent, granica detekcije i granica određivanja; također su procijenjeni ispravnost i preciznost. Relativna pogreška kretala se u rasponu $-1,7$ do 1,8\%, a RSD vrijednosti između 1,0 i 1,1\%. Metoda je uspješno primjenjena za određivanje PFM u tabletama $s$ analitičkim povratom od 97,5 do $101,9 \%$ uz RSD od 0,6 do 1,9\%. Rezultati su statistički uspoređeni s referentnom metodom pomoću Studentovog $t$-testa i $F$-testa, ukazujući na usporedivu preciznost i ispravnost obiju metoda. Ispravnost procijenjena metodom standardne adicije kretala se $u$ rasponu od 97,0 do $106,0 \%$, s preciznošću (RSD) boljom od 3\%.

Ključne riječi: pefloksacin mesilat, određivanje, spektrofotometrija, bromfenol modrilo, ljekoviti oblici

Department of Chemistry, University of Mysore, Manasagangotri, Mysore-570 006, India 